\title{
ON ESTIMATION OF THE STRUCTURAL ELEMENTS DAMAGE ACCORDING TO COERCIVE FORCE. MESSAGE 3. RESULTS OF EXPERIMENTAL STUDIES OF THE POSSIBILITY OF USING A COERCIVE-METRIC CONTROL TO ESTIMATE THE DEGREE OF DAMAGE OF FERROMAGNETIC STEELS UNDER MECHANICAL LOADING
}

\section{Oleksii Gopkalo $^{1}$; Volodymyr Nekhotiashchiy ${ }^{2}$; Gennadii Bezlyudko ${ }^{3}$; Yurij Kurash ${ }^{1}$}

\author{
${ }^{1}$ Institute for Problems of Strength named after G. S. Pisarenko, \\ National Academy of Sciences of Ukraine, Kyiv, Ukraine \\ ${ }^{2}$ Institute of Electric Welding named after E. O. Paton, \\ National Academy of Sciences of Ukraine, Kyiv, Ukraine \\ ${ }^{3}$ LLC «Special Scientific Developments», Kharkiv, Ukraine
}

\begin{abstract}
Summary. This paper presents the results of experimental studies on the response of the coercive force to the mechanical loads of laboratory samples from ferromagnetic steels of 05kp, 17G1C and steel 20. It is shown that the differences in the response of the coercive force to the mechanical loads of ferromagnetic and austenitic steels are in the physical nature of these phenomena. For ferromagnetic steels, changes in the values of coercive force in static and cyclic deformation are associated with the ordering of the domain structure of the metal (from chaotic to directed). For paramagnetic (non-magnetic in the initial state), changes in the values of coercive force in static and cyclic deformation are associated with structural transformations of the original austenite into a deformation martensitic with a finite ferrito-perlite decay, which causes a change in the magnetic properties of the metal from the paramagnetic into the ferromagnetic state. The device proposed by the author with the modified design of the sensor allowed to obtain new data on the response of the coercive force to mechanical loads and to establish the basic laws of deformation and destruction of the metal in the most loaded and damaged local zones, including areas of stress concentration, elements of structures made of ferromagnetic steels. It has been experimentally established that when measured in mechanical load, the measured values of the coercive force depend on the orientation of the poles of the sensor magnets relative to the direction of loading. At static or cyclic loading to stresses that exceed the boundary of fluidity, after unloading, the value of coercive force in 1,5-2 times exceeds the same values in the loaded state. At the same time, in the case of static or cyclic loading with excess of the existing stresses of the boundary of flux during unloading, there is a reversible turn in 900 directions of the maximum values of the coercive force that causes the corresponding «jump» of these values. The detection of a sharp change in the values of the coercive force, in excess of the stresses of the boundary of fluidity, during the monitoring of the VAT of structural elements allows to establish the boundaries of plastic and elastically deformed metal and may be the background for the use of other non-destructive research methods, for example, measuring the thickness of the metal and finding defects. The use of a coercimetry control allows separating the damage that is obtained in the metal under conditions of elastic deformation and damage caused by elastic-plastic and plastic deformation, as well as destruction. The dependence of the values of the coercive force on the orientation of the direction of measurement relatively the direction of loading allows us to determine the direction of the main stresses. The present results can be useful in diagnosing the quality of modern technologies, for example, the local
\end{abstract}


On estimation of the structural elements damage according to coercive force. Message 3. Results of experimental studies of the possibility of using a coercive-metric control to estimate the degree of damage of ferromagnetic steels under mechanical loading

heat treatment of constructive elements of the type «thermoshocks» and in developing a method for evaluating the residual stresses from welding. The experimental results obtained give an optimistic prediction of the possibility of using a coercimetric control to monitor the accumulation of damage in ferromagnetic metals by changing the values of the coercive force.

Key words: structurescope, coercive force, load, damage, stress, deformation, destruction.

Response of the coercive force to the small-cycle «soft» loading of samples without stress concentratrators. Experimental investigations of the coercive force response to the static and cyclic tension were carried out on the laboratory samples made of steel 05кп the sizes

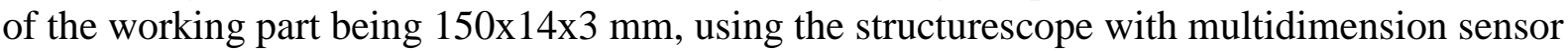
D65 (measuring base is $65 \mathrm{~mm}$ ). In Figure 1 a the diagram of the samples tension and the dependence of the coercive force $H c$ on deformation $(\varepsilon)$ under gradual short-term step-by-step load $(P)$ with the further unloading to the $P=0$, is presented. In the Figure $1 \mathrm{~b}$ the diagram of the deformation kinetics and the coercive force values $H c$ according to the number of cycles of the applied forces with the unloading at the cyclic tension is presented, the cyclic tension being of frequency 2 cycles/min. It should be noted, that at the initial state the value of the coercive force for steel $05 \kappa \Pi$ was about $2 \mathrm{~A} / \mathrm{cm}$.

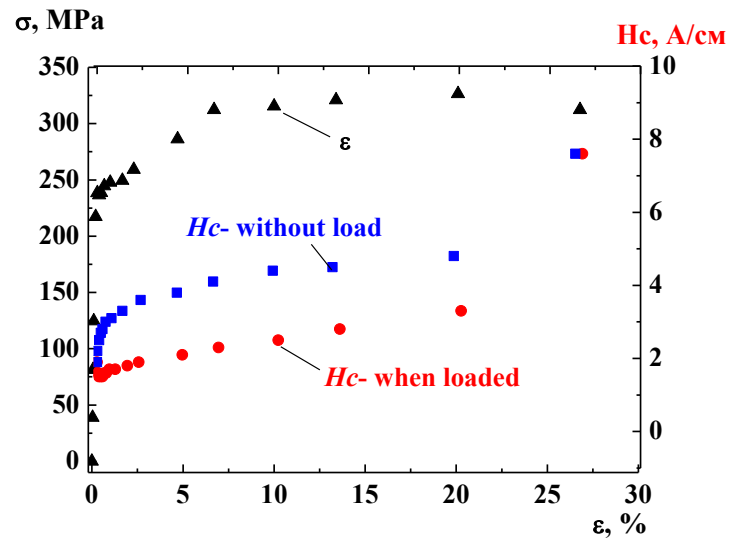

a)

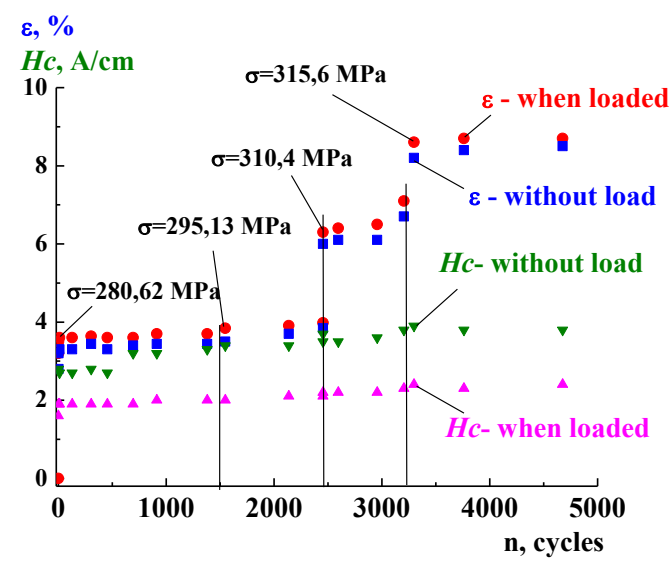

b)

Figure 1. The striation pattern of the samples and the dependence of the coercitive force $H c$ (sensor D65) on the deformations $(\varepsilon)$ under a short-term gradual step-by-step loading $(P)$ with an unloading to the values $P=O(a)$ and the kinetics of the deformations and the values of the coercive force $H c$ according to the number of cycles of the applied effort with the unloading at the cyclic tension of frequency 2 cycles/min. $(b)$

The obtained data show, that the number the static and cyclic tension and, being unloaded at every stage, the values of the coercive force in the unloaded state and measured in the same direction, are in about 1,5-2 times higher than those in the loaded state at the same stage of loading. It should be noted, that critical values of $H c$ before fracture in the loaded and unloaded states coincide and equal $7,8 \mathrm{~A} / \mathrm{cm}$. The values of the coercive force before fracture almost in 4 time exceed the similar values at the initial state of the metal.

The application of the smalldimension sensor D12 made possible to determine the dependence of the coercive force values on the orientation of the sensor poles relatively the loading direction under static and cyclic tension of the laboratory samples with the sizes of the working part $135 \times 26 \times 2,0 \mathrm{~mm}$, made of the pipe $\varnothing 630 \times 8$ of steel $17 \Gamma 1 \mathrm{C}$ after long-term operation of the heating plants. The experimental results of the cyclic-tension testing of the laboratory samples, being under real hydraulic loading conditions and corrosion wearing, are 
presented below. During testings the cyclic tension stresses, simulating the hydraulic loading, were $1,15 \ldots 1,25$ of the stresses of the standard mode of the heating plants operation. Corrosion wearing was simulated while raising the acting stresses by $7 \%$. The conventional yield boundary of the pipe metal was $\sigma_{0,2}=413,2 \mathrm{MPa}$. It should be noted, that the minimum initial values of the coercive force were $5,2 \mathrm{~A} / \mathrm{cm}$ and the tips of the magnet poles were located across the sample direction (along the rolling) and 7,5 A/cm, when the tips of the magnet poles were along the sample direction (across the rolling), which is associated with the anisotropy of the metal mechanical properties, which is the characteristics of the pipe steels $[1,2,3]$.

In Figure $2 \mathrm{a}, \mathrm{b}$ the kinetics of the coercive force of the fracture area being in the loaded state under the cyclic tension stresses and orientation of the magnet pole tips across (a) and along (b) the working part of the sample are presented. Here $\sigma_{\max }-$ are stresses simulated by the hydraulic testings, $\sigma_{\text {min }}$ - are stresses under the standard mode of loading. It should be noted, that, when the magnet pole tips are oriented across the working part of the sample (Fig. 2 a) irrespective of the stress value, the monotonic growth of the coercive force values takes place, their values being sufficiently greater under fracture.

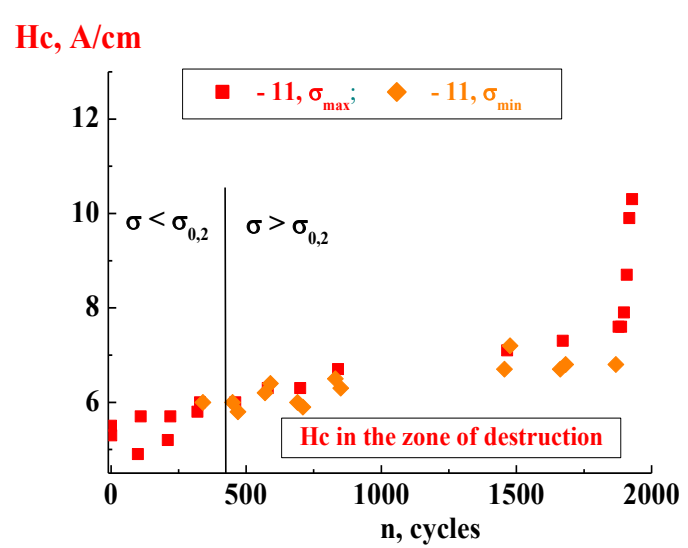

a)

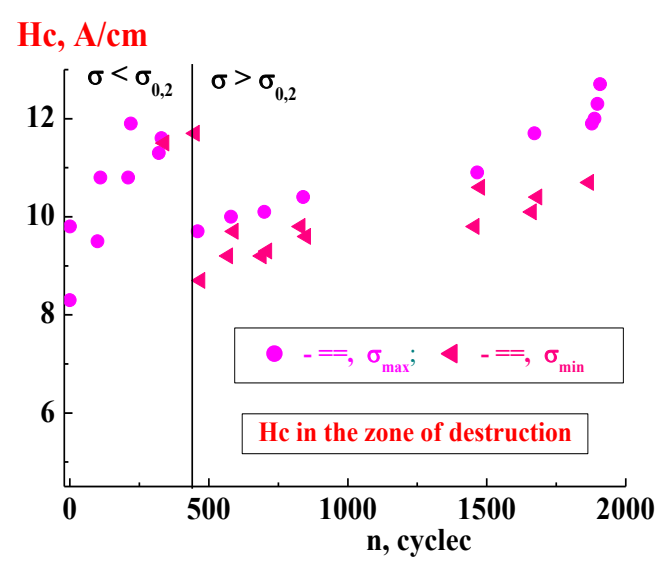

b)

Figure 2. Kinetics of the coercive force in the zone of destruction in the loaded state under the action of cyclic tensile stresses and orientation of the tips of the poles of the magnets across $(a)$ and along $(b)$ the working part of the sample

Being in the loaded state, when the magnet pole tips are oriented along the working part of the sample under elastic deformation $\left(\sigma<\sigma_{0,2}\right)$, the increase of the coercive force values takes place up till their maximum values, when the conventional yield boundary of stresses is reached, and further, when stresses are increased $\left(\sigma>\sigma_{0,2}\right)$, their rapid decrease takes place (jump) about $20 \%$ of the coercive force value. During the further cyclic tension, when stresses grow, the gradual increase of the coercive force values takes place, which under fracture are about equal to that of the conventional yield boundary.

In the Figure $3 \mathrm{a}, \mathrm{b}$ the kinetics of the coercive force in the fracture area of the sample being in the unloaded state after cyclic loading, when the magnet pole tips are oriented across (a) and along (b) the working part of the sample, is presented. In the unloaded state (Fig. 3 a), when the magnet pole tips are oriented across the working part of the sample after stresses exceeding the values of the conventional metal yield boundary $\sigma>\sigma_{0,2}$, rapid, almost in two times higher growth of the coercive force values takes place, which, in fact, does not change its values up till fracture. And only during fracture the growth of values $H c$ takes place by $14 \%$.

In the unloaded state, when the magnet pole tips are oriented along the working part of the sample (Fig. 3 b), after stresses exceeding the conventional yield boundary of the metal, 
rapid decrease of the coercive force values by $27 \%$, which gradually increase, takes place. During the fracture the rapid increase of the coercive force values takes place up to the value, which is about the values of the coercive force after the elastic stresses, which do not exceed the conventional yield boundary $\left(\sigma<\sigma_{0,2}\right)$.

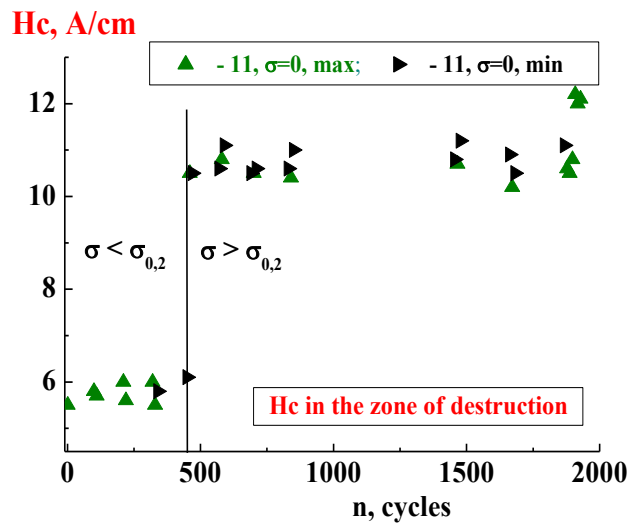

a)

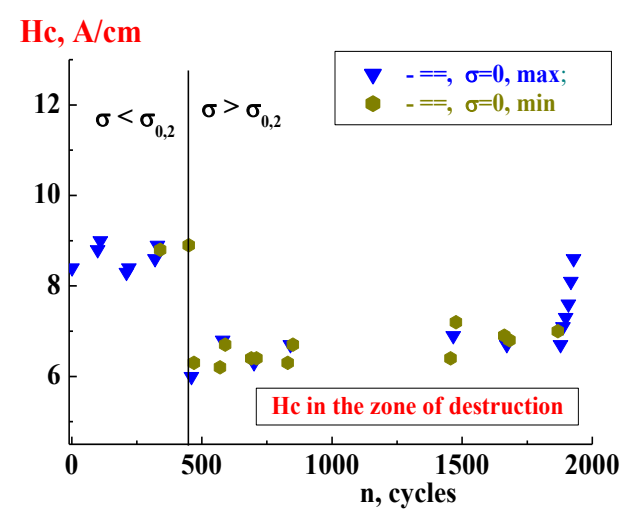

b)

Figure 3. Kinetics of the coercive force in the area of the sample fracture in the unloaded state after cyclic loading when the tips of the poles of the magnets are oriented across $(a)$ and along $(b)$ the working part of the sample

It should be noted, that in the loaded state (Fig. 4 a), when the magnet pole tips are oriented along the sample (the direction of the magnetization force lines of magnetic field is oriented across the longitudinal axis of the sample), the direction of the maximum values of the coercive force coincides with the loading direction. In the unloaded state after loading (Fig. 4 b) the direction of the maximum values of the coercive force is oriented parallel to the loading direction and corresponds the orientation of the magnet pole tips across the sample (the direction of the magnetization force lines of magnetic field). Here, after the plastic deformation of the metal $\left(\sigma>\sigma_{0,2}\right)$ under unloading up to $\sigma=0$ the turn in $90^{\circ}$ of the maximum values of the coercive force takes place. Similar mechanisms of behavior of the ferromagnetic steels magnetic properties under loading with the further unloading are described in the papers $[4,5,6]$.

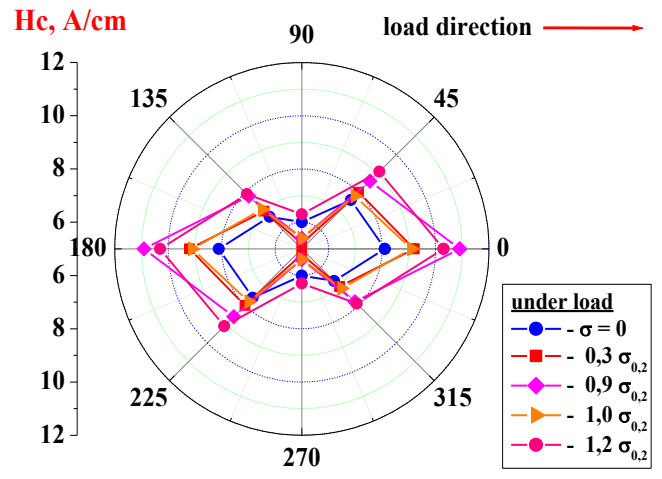

a)

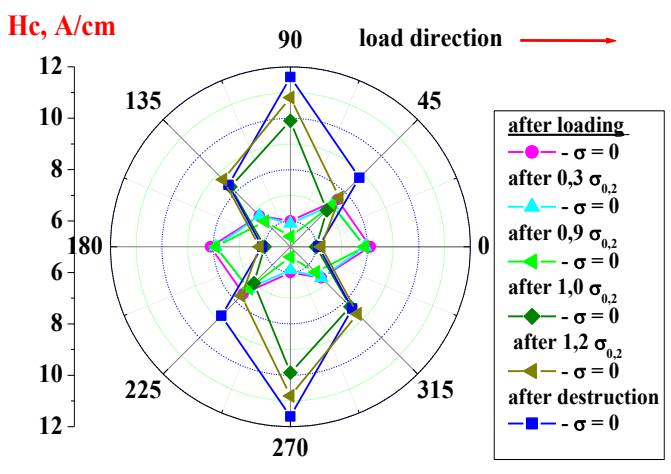

b)

Figure 4. Graphs of the distribution of the values of the coercive force on the surface of the laboratory sample in the loaded state $(a)$ and after loading (unloaded state) $(b)$ 
Response of the coercive force to the small-cycle «soft» loading of samples with the stress concentrators. Experimental investigations of the coercive force response to the cyclic tension were carried out on the laboratory samples made of steel $17 \Gamma 1 \mathrm{C}$ with the stress concentrators in the form of 5 through holes: $\varnothing 0,5 \mathrm{~mm} ; \varnothing 1,0 \mathrm{~mm} ; \varnothing 1,5 \mathrm{~mm} ; \varnothing 2,0 \mathrm{~mm}$ and $\varnothing 2,5 \mathrm{~mm}$ (Fig. 5).

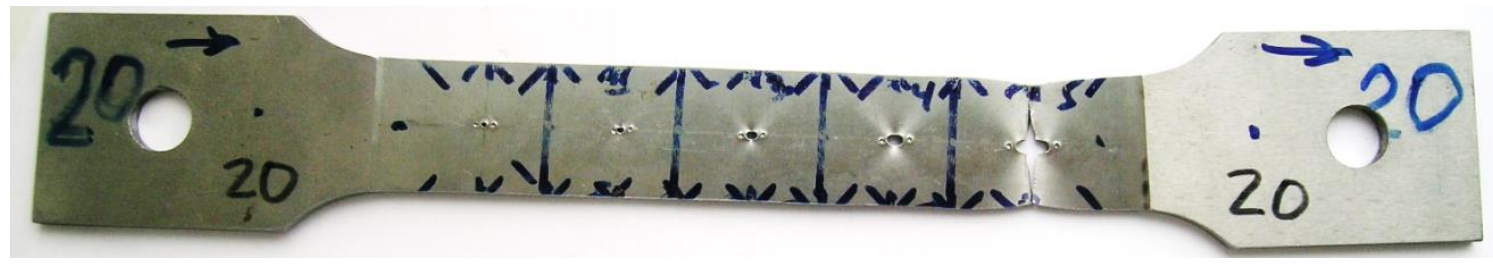

Figure 5. Photos of sample with stress concentrators in the form of through holes: $\varnothing 0.5 \mathrm{~mm}: \varnothing 1.0 \mathrm{~mm}$; $\varnothing 1.5 \mathrm{~mm} ; \varnothing 2.0 \mathrm{~mm}$ and $\varnothing 2.5 \mathrm{~mm}$ after testing

In the Figure 6 the graphs of distribution of the coercive force values along the surface of the laboratory sample with the stress concentrators in the form of through holes: a) $-\varnothing 0,5 \mathrm{~mm} ; b)-\varnothing 2,0 \mathrm{~mm} ; c)-\varnothing 2,5 \mathrm{~mm}$ under elastic (left column) and plastic (right column) deformation. In the figure the graphs of the coercive force distribution along the surface of the laboratory sample with the stress concentrators under the loaded state are marked by the red colours and in the unloaded state (after some loading) - in blue-green colours.

After the elastic deformation till the stress gross values $0,9 \sigma_{0,2}$ of the metal in the area of the stress concentrators from the holes $\varnothing 0,5 \mathrm{~mm}, \varnothing 1,0 \mathrm{~mm}$ and $\varnothing 1,5 \mathrm{~mm}$ in the unloaded state the maximum values of the coercive force are of $71,4 \%$ of the loaded state (Fig. $6 \mathrm{a}-$ is elastic deformation) and their direction coincides with the loading direction. Here, presented in Figure 6 a the appearance of graphs for the coercive force distribution on the sample surface under the elastic deformation in the area of the hole $\varnothing 0,5 \mathrm{~mm}$ is similar to that of the $H c$ graph for the samples with the holes $\varnothing 1,0 \mathrm{~mm}$ and $\varnothing 1,5 \mathrm{~mm}$. After elastic deformation up to the stress gross values $0,9 \sigma_{0,2}$ of the metal in the unloaded state $(\sigma=0)$ in the area of stress concentrators from the holes $\varnothing 2 \mathrm{~mm}$ and $\varnothing 2,5 \mathrm{~mm}$ (the nominal stresses were equal to 402,98 $\mathrm{MPa}$ and 411,19 $\mathrm{MPa}$ respectively and lower than the conventional yield boundary $\sigma_{0,2}=$ 413,2 MPa), there happened the increase of the coercive force values relatively the similar areas with the concentrators holes $\varnothing 0,5 \mathrm{~mm}, \varnothing 1,0 \mathrm{~mm}$ and $\varnothing 1,5 \mathrm{~mm}$. Here, after the elastic deformation in the concetrator from the holes $\varnothing 2,0 \mathrm{~mm}$ and $\varnothing 2,5 \mathrm{~mm}$ under unloading, the device registers the maximum values $H c$ being turned in the direction of $90^{\circ}$ (Fig. 6 b, c-elastic deformation)

The increase of the hole diameter from $\varnothing 2,0 \mathrm{~mm}$ to $\varnothing 2,5 \mathrm{~mm}$ under elastic deformation till the stress gross values $0,9 \sigma_{0,2}$ causes the increase of the volume of the elastically deformed metal in the local area of the hole, and, correspondingly, increase of the coercive force values in the unloaded state (relatively the loaded state) from $82 \%$ (for the hole $\varnothing 2,0 \mathrm{~mm}$ ) till $100 \%$ (for the hole $\varnothing 2,5 \mathrm{~mm}$, where the value $H c$ in the loaded and unloaded states almost coincides, Figure $6 \mathrm{c}$ - elastic deformation). Registered by the device growth of the coercive force values in the unloaded state after loading till the gross stresses $0,9 \sigma_{0,2}$ in the area of the stress concentrators from the holes $\varnothing 2 \mathrm{~mm}$ and $\varnothing 2,5 \mathrm{~mm}$ is associated with the sensor sensitivity to the volume of the elastically deformed metal in the area of measuring, where the acting stresses exceeded that conventional yield boundary, which specify the change of direction (turning in $90^{\circ}$ and the absolute values $H c$ (Fig. 6 b, c-elastic deformation). 
On estimation of the structural elements damage according to coercive force. Message 3. Results of experimental studies of the possibility of using a coercive-metric control to estimate the degree of damage of ferromagnetic steels under mechanical loading
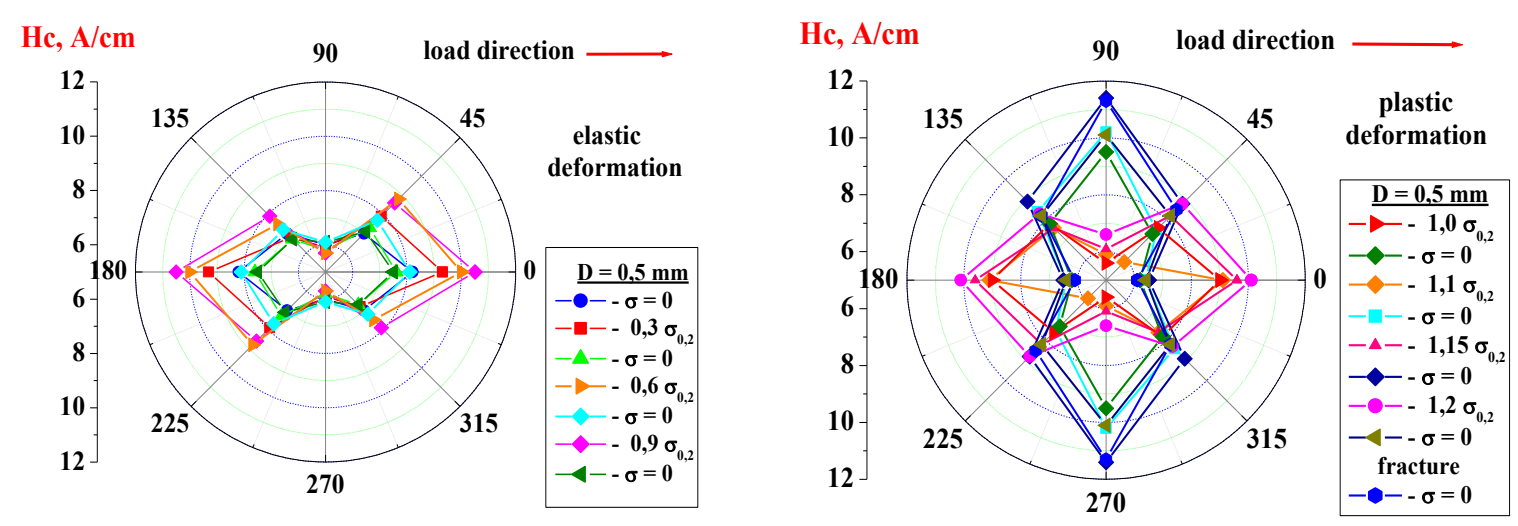

a)
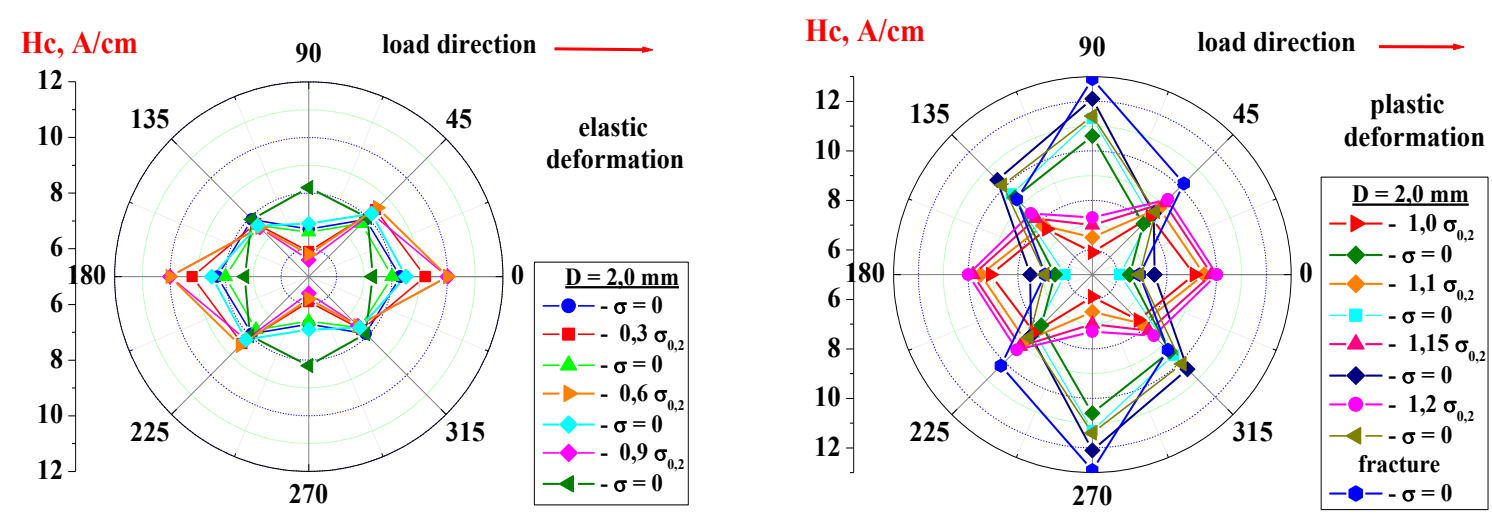

b)
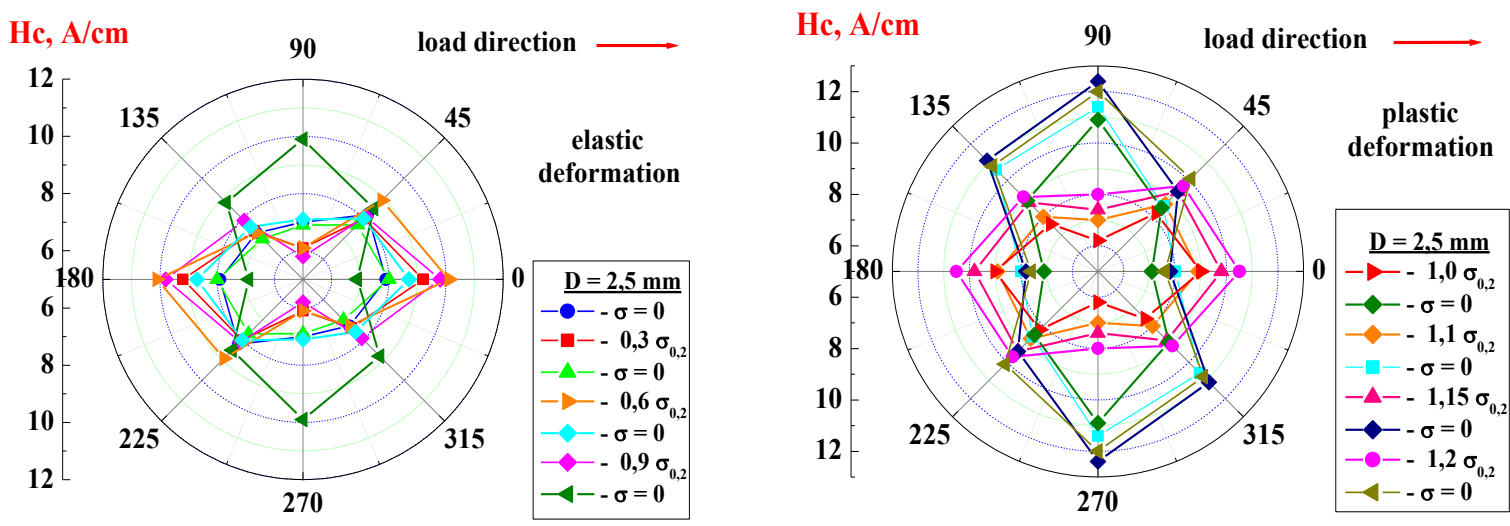

c)

Figure 6. Diagrams of the distribution of the values of the coercive force on the surface of the laboratory sample with the stress concentrators in the form of openings: $(a)-\varnothing 0.5 \mathrm{~mm} ;(b)-\varnothing 2.0 \mathrm{~mm}$;

(c) $-2.5 \mathrm{~mm}$ for elastic (left column) and plastic (right column) deformation

It should be stressed, that if the coercive force does not response to the elastic deformation of the gross stresses of $0,9 \sigma_{0,2}$ of the samples with the stress concentrators from the holes of $\varnothing 0,5 \mathrm{~mm}, \varnothing 1,0 \mathrm{~mm}$ and $\varnothing 1,5 \mathrm{~mm}$, it is caused by the unsufficient sensitivity of the sensor to the small volume of the plastically deformed metal in the area of measuring, where the acting stresses exceed the conventional yield boundary. The value of the volume of the 
plastically deformed metal, where the sufficient change of orientation of the metal domain structure in the area of measuring takes place, depends on the distribution of normal stresses $\sigma_{x}$ in the depth and surface of the hole, (Fig. 7 a, b) $[4,5,6]$.

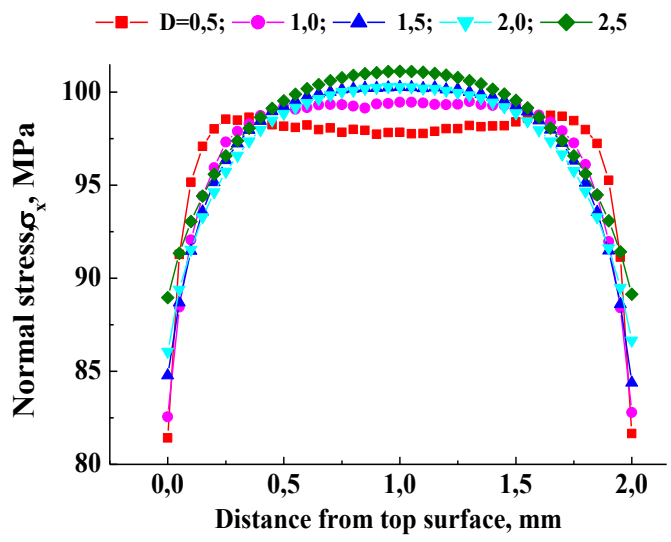

a)

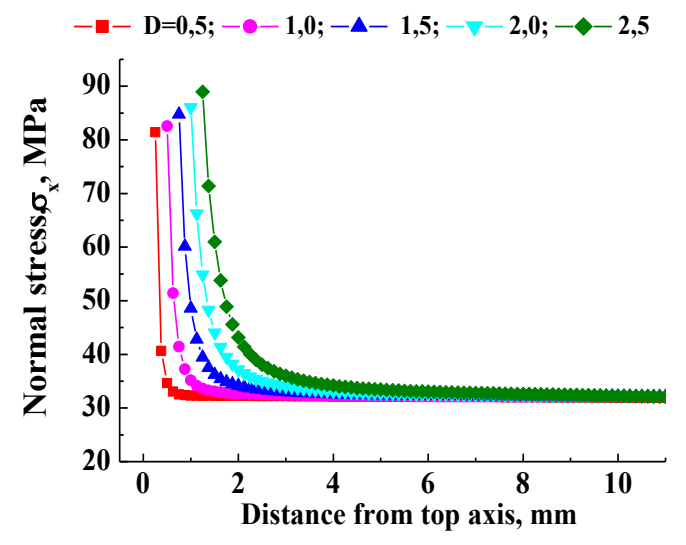

b)

Figure 7. Distribution of normal stresses in the depth of the hole (a) and its surface $(b)$

Thus, the sensitivity of device with the sensor D12 for measuring the values of coercive force to the stresses concentration is specified by the correlation of elastically and plastically deformed metal values in the area of measuring. It can be the base for the development of the non-fractured methods for estimation of stresses in the area of stresses concentration.

Under the plastic deformation (Fig. $6 \mathrm{a}, \mathrm{b}, \mathrm{c}$-plastic deformation) in the area of the stress concentrators from the holes $\varnothing 0,5 \mathrm{~mm}, \varnothing 2,0 \mathrm{~mm}$ and $\varnothing 2,5 \mathrm{~mm}$ in the unloaded state the maximum values of the coercive force equal $(113,4-129,4) \%$ of the similar values in the loaded state.

If the kinetics of the coercive force under step-by-step loading with unloading is analyzed, it should be stressed that under elastic deformation $\left(\sigma<\sigma_{0,2}\right)$ irrespective of the available stress concentrators and depending on the value of the applied stresses, the values $H c$ in the unloaded state can be equal 70-90\% of the similar values in the loaded state (Fig. 8) and their direction coincides with the loading direction. Under the plastic deformation ( $\left.\sigma>\sigma_{0,2}\right)$, depending on the value of stresses being applied, the value of the coercive force in the unloaded state can be equal to $114,2-140,8 \%$ of the similar values in the loaded state. Here, in the unloaded state after the step-by-step loading with unloading during the transition from elastic to plastic deformation, the turning in $90^{\circ}$ takes place towards the maximum values of the coercive force (in Fig. 8 it is not shown). Thus, under elastic deformation in the loaded state the values of the coercive force are higher than those similar ones in the unloaded state and their direction coincides with the loading direction. Although, under plastic deformation, on the contrary, the values of the coercive force in the loaded state are lower, than those similar values in the unloaded state, and during the transition from elastic to plastic deformation the turning in $90^{\circ}$ takes place towards the maximum values of the coercive force. 


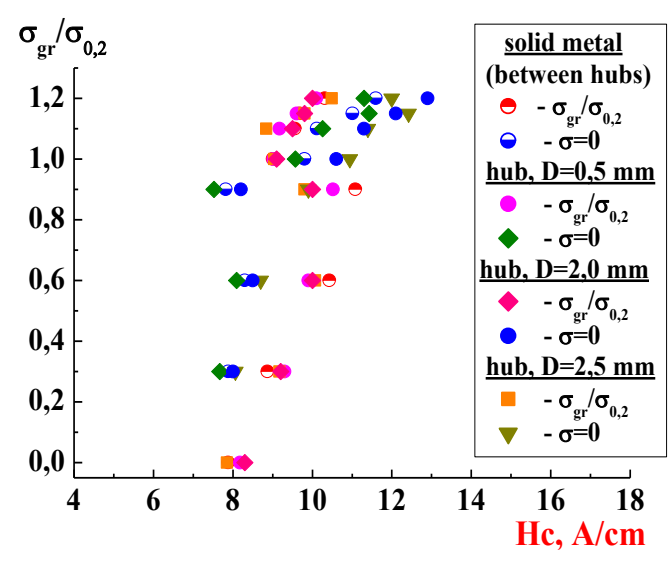

Figure 8. Kinetics of coercive force outside the stress concentrators (between concentrators) and in the hole area $\varnothing 0.5 \mathrm{~mm}, \varnothing 2.0 \mathrm{~mm}$ and $2.5 \mathrm{~mm}$ under step-by-step loading with unloading, depending on the value of stress

Response of the coercive force to the multicycle loading of samples without the stress concentrators. In order to determine the response of the coercive force to the multicycle loading the testings of the laboratory samples made of steel 20 without the stress concentrators with the sizes of the working part $12 \times 20 \times 5,8 \mathrm{~mm}$ have been carried out under the axis signvariable tension-compression of the frequency $84 \mathrm{~Hz}$ at the yield boundary stresses ( $\left.\sigma_{a}=169,5 M \Pi a\right)$ and the stress cycle asymmetry $R_{\sigma}=-1$.

In the Figure 9 the kinetics of the coercive force values according to the number of loading cycles in the area of sample fracture under the orientation of the sensor magnet pole tips across (a) and along (b) the working part of the sample is presented. As during the scanning of the coercive force values on the sample working part surface and the adjacent to it areas the measuring was performed with the step of $6 \mathrm{~mm}$ (half of the device meter base), the value $H c$ was found twice, in the fracture area in particular. It should be stressed, that the fracture of laboratory samples occurred along the fillet (transition area from the working part along the radius till the area of clamp in the active capture) of the sample, the stresses amplitude being $\sigma_{a}^{f}=0,87 \sigma_{a}^{n}$ of the nominal stresses $\left(\sigma_{a}^{n}\right)$ with the minimal cross-section area along the middle of the working part of the sample. Initiation of the sample fracture was accompanied by the rapid decrease of the loading frequency resulted from the crack growth. Here, because of the fact, that the sensor measuring base is large enough, and the fatigue crack square being 0,25 of the nominal square of the cross-section in the fracture area, the changes of the coercive force values were not registered. And, only under the further growth of the fatigue crack till the fatigue crack square up to 0,5 of the nominal square of the cross section in the area of fracture, the sufficient changes of the coercive force values have been registered in the fracture area. Thus, under the multicycle fatigue the device overall dimension sensor is able to register only large enough cracks, when the metal fracture starts affecting the values of the magnetic characteristics in the area of measuring the coercive force. That is, under the multicyclic fatigue, when the basic volume of the metal in the area of measuring undergoes the elastic deformation without sufficient changes of the magnetic characteristics values, the sensitivity of the device to the coercive force response to the cracks initiation is specified by their sizes. 

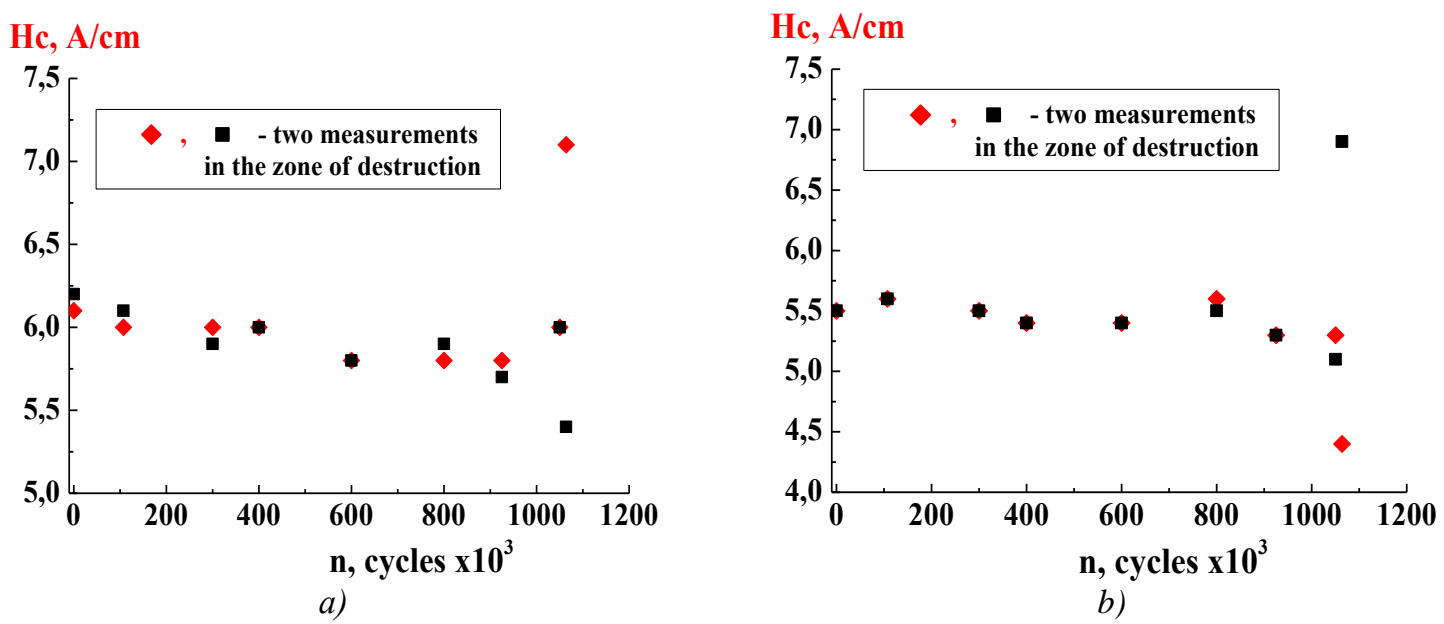

Figure 9. Kinetics of the coercive force values in terms of the number of loading cycles in the area of fracture of the sample when the tips of the magnet poles of the sensor are oriented across $(a)$ and along $(b)$ the working part of the sample

Generalization of the investigation experimental results. The presented device with the improved design of the sensor makes possible to obtain new data on the response of the coercive force to the mechanical loadings and to determine the main regularities of metal deformation and fracture at the most loaded and fractured local areas, in the areas of the stresses concentration in particular, of the structure elements made of the ferromagnetic steels.

The analysis of the obtained results is promising for the possibilities to apply the coercive-metric control for monitoring the fracture accumulation according to the change of the coercive force values. Here, it should be stressed that under elastic-plastic static and cyclic deformation the application of the coercive-metric control makes possible to separate fractures obtained in the metal under elastic deformations and those obtained under elastic-plastic and plastic deformations up till the fracture. Rapid increase of the coercive force values up to the critical values before the fracture itself, irrespective of the sensor magnet tips orientation direction relatively the investigated surface and the loaded state, testifies the sufficient plastic deformations to be available. Dependence of the coercive force values on the orientation direction measuring relatively the loading direction makes possible to determine the direction of the main stresses.

The rapid change of the coercive force values, when the conventional yield boundary stresses are exceeded, can be used for finding the boundaries of the elastically and plastically deformed metal while monitoring the structure elements stressed state. The obtained regularities of the coercive force response to the elastic and plastic deformation can be the basic interpreting for application of other, non-fracture methods of investigation, e.g. , measuring of the metal thickness, estimation of stresses and deformations, search for defects, etc.

In the areas of the stresses concentration the sensitivity of the device for measuring the values of the coercive force is determined by the elastic and plastic relation of the strained metal volumes in the area of measuring. This condition can be the base for the development of nonfracture methods for estimation the stresses (the residual stresses in particular) in the area of the stresses concentration.

For the ferromagnetic steels multicycle fatigue range the device can not determine the metal strength limit, as it was found for the paramagnetic steels. The sensitivity of the device in the response of the coercive force to the cracks initiation is specified by its dimensions. At the stage of the fatigue cracks development the dimensions of the device sensor make possible 
On estimation of the structural elements damage according to coercive force. Message 3. Results of experimental studies of the possibility of using a coercive-metric control to estimate the degree of damage of ferromagnetic steels under mechanical loading

to register only large enough cracks, when a great part of the metal integrity loss starts affecting the values of the magnetic characteristics in the area of the coercive force measuring.

The obtained results can be worth being used for the estimation of the obtained damages in the areas of the local deformation of the product part, during the diagnostics of modern technologies quality, local heat treatment of the structural elements of the «thermal shock» type and while developing the methods for estimation of the residual stresses in the areas of the stresses concentration and during welding.

The results of experimental investigations make possible to increase the possibility of application of the coercive-metric control for estimation of the accumulated damages in metals under static and cyclic loading and can be the base for the development of new approaches to the express-estimation of the residual service life of the structures metal taking advantage of the simple non-fracture method.

Conclusion. The experimental interpreting of the possibility to estimate the level of metal fracture of structures made of ferromagnetic steels according to the results of measuring the coercive force, was carried out. Substantial differences of response of metal coercive force of the structures made of ferromagnetic and paramagnetic steels to the mechanical loadings and unloadings after mechanical loadings have been determined. The change of the magnetic properties under deformation of the austenite steel (paramagnetic in the finishing state) is associated with the ability of this steel to undergo the structural transformations (paramagnetic) of austenite $\gamma \rightarrow \alpha$ and appearance of the ferromagnetic phase $(\alpha-\mathrm{Fe})$ being formed in the austenite steel $(\gamma-\mathrm{Fe})$ containing martensite - and ferrite-deformations, which result in the transition of the metal from paramagnetic into ferromagnetic state. For the ferromagnetic steels the change of metal magnetic properties under deformation is associated with the domains orientation regulation (from the chaotic state to the oriented one). It was determined experimentally, that for ferromagnetic steels after the first overloading of metal (the acting stresses exceeded the conventional yield boundary), being unloaded till zero values of acting stresses, the «jump» and the change of direction in $90^{\circ}$ of maximum coercive forces, take place, here their maximum values in the unloaded state being unchanged. This characteristics can be used in practice for the control of loading value of main structural elements under operation. The possibility of application of the improved structurescope for finding the boundaries of the most fractured areas, the main stresses direction being determined too, was shown. Application of the coercive-metric control under structures operation makes possible to adapt the measuring results of the coercive force values changes in the most loaded areas to the obtained fractures. The limits in the possibility to estimate the level of metal fracture according to the coercive force values in the areas of the stresses concentration under cyclic loading were determined, which are caused by the device sensitivity (at the given sensor dimensions for measuring $\mathrm{Hc}$ ) to the elastic and plastic relation of the deformed metal volume in the area of fracture (measuring). The obtained results can be the base for the development of new approaches for the express-estimation of the residual service life of structures metal using the simple nonfracture method.

Роботу виконано в рамках науково-дослідної роботи відділу втоми і термовтоми матеріалів Інституту проблем міцності імені Г. С. Писаренка НАН України за темою 1.3.4.1910 «Розробка методів оцінки втомного пошкодження металічних матеріалів на стадіях зародження і росту тріщин».

\section{References}

1. Gorkunov E. S., Mitropolskaya S. Yu., Vichuzhanin D. I., Tueva E. A. Primenenie magnitnyh metodov dlya ocenki nagruzhennosti i povrezhdennosti stali X70. Fizicheskaya mezomehanika. 2010. № 13. P. 7382. [In Russian]. 
2. Matrosov Yu. I., Litvinenko D. A., Golovanenko S. A. Stal dlya magistralnyh. M.: Metallurgiya, 1989. 288 p. [In Russian].

3. Vonsovskij S. V., Shur Ya. S. Ferromagnetizm. M.: OGTZ, 1948. 816 p. [In Russian].

4. Malahov O. V., Kochergin A. V., Devyatkin D. S. Persperktivy primeneniya metoda magnitnoj pamyati metallov $\mathrm{k}$ diagnostike sostoyaniya metallov. Vostochno-Evropejskij zhurnal peredovyh tehnologij. ISSN 1729-3774. 4/5 (64). 2013. P. 20-24. [In Russian].

5. Kuleev V. G., Carkova T. I., Nipichuruk A. P. Issledovanie prichin sushestvennyh razlichij velichin koercitivnoj sily, ostatochnoj namagnichennosti i nachalnoj magnitnoj pronicaemosti ferromagnitnyh stalej $\mathrm{v}$ nagruzhennom sostoyanii pri ih plasticheskom rastyazhenii. FMM. 2007. T. 103. № 2. P. 136-146. [In Russian].

6. Carkova T. P., Kuleev V. G. Osobennosti magnitouprugogo effekta v plasticheski deformirovannyh ferromagnitnyh stalyah v slabyh magnitnyh polyah. FMM. 2009. T. 108. № 3. P. 227-236. [In Russian].

\title{
Список використаної літератури
}

1. Горкунов Э. С., Митропольская С. Ю., Вичужанин Д. И., Туева Е. А. Применение магнитных методов для оценки нагруженности и поврежденности стали Х70. Физическая мезомеханика. 2010. № 13. С. 73-82.

2. Матросов Ю. И., Литвиненко Д. А., Голованенко С. А. Сталь для магистральных газопроводов. М.: Металлургия, 1989. 288 с.

3. Вонсовский С. В., Шур Я. С. Ферромагнетизм. М.: ОГТЗ, 1948. 816 с.

4. Малахов О. В., Кочергин А. В., Девяткин Д. С. Персперктивы применения метода магнитной памяти металлов к диагностике состояния металлов. Восточно-Европейский журнал передовых технологий. ISSN 1729-3774. 4/5 (64). 2013. С. 20-24.

5. Кулеев В. Г., Царькова Т. И., Нипичурук А. П. Исследование причин существенных различий величин коэрцитивной силы, остаточной намагниченности и начальной магнитной проницаемости ферромагнитных сталей в нагруженном состоянии при их пластическом растяжении. ФММ. 2007. T. 103. № 2. С. 136-146.

6. Царькова Т. П., Кулеев В. Г. Особенности магнитоупругого эффекта в пластически деформированных ферромагнитных сталях в слабых магнитных полях. ФММ. 2009. Т. 108. № 3. C. $227-236$.

\section{УДК 539.4}

\section{ОЦІНКА ПОШКОДЖЕНОСТІ ЕЛЕМЕНТІВ КОНСТРУКЦІЙ ЗА ВИМІРАМИ КОЕРЦИТИВНОЇ СИЛИ. ПОВІДОМЛЕННЯ З. ФЕРОМАГНІТНІ СТАЛІ ЗА МЕХАНІЧНОГО НАВАНТАЖЕННЯ}

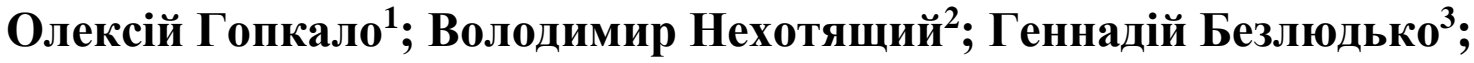 Юрій Кураш ${ }^{1}$}

\author{
${ }^{1}$ Інститут проблем міцності імені Г. С. Писаренка НАН Украӥни, \\ Київ, Україна \\ ${ }^{2}$ Інститут електрозварювання імені С. О. Патона НАН України, \\ Київ, Украӥна \\ ${ }^{3} \mathrm{OOO}$ «Специальные научные разработки», Харків, Украӥна
}

\footnotetext{
Резюме. Наведено результати експериментальних досліджень реагування коерцитивної сили на механічні навантаження лабораторних зразків із феромагнітних сталей 05кn, 17Г1С та сталі 20. Показано, щзо відмінності у реагуванні коерцитивної сили на механічні навантаження феромагнітних та
} 
On estimation of the structural elements damage according to coercive force. Message 3. Results of experimental studies of the possibility of using a coercive-metric control to estimate the degree of damage of ferromagnetic steels under mechanical loading

аустенітних сталей полягають у фізичній природі ции явищ. Для феромагнітних сталей зміни значень коерцитивної сили при статичному та циклічному деформуванні пов'язані з упорядкуванням орієнтації доменної структури металу (від хаотичної до направленої). Для парамагнітних (не магнітних у початковому стані) сталей зміни значень коерцитивної сили при статичному та циклічному деформуванні пов'язані зі структурними перетвореннями вихідного аустеніту в деформаційний мартенсит з кінцевим ферито-перлітним розпадом, щзо викликає зміну магнітних властивостей металу з парамагнітного у феромагнітний стан. Запропонований авторами прилад зі зміненою конструкцією датчика дозволив отримати нові дані реагування коерцитивної сили на механічні навантаження $i$ встановити основні закономірності деформування та руйнування металу у найбільш навантажених та пошкоджених локальних зонах, у тому числі зонах концентрації напружень, елементів конструкцій із феромагнітних сталей. Експериментально встановлено, що при механічному навантаженні виміряні значення коерцитивної сили залежать від орієнтації полюсів магнітів датчика відносно напрямку навантаження. При статичному або ицилічному навантаженні до напружень, які перевищували умовну межу плинності, після розвантаження значення коерцитивної сили у 1,5-2 раза перевищують аналогічні значення у навантаженому стані. При цььому за статичного або циклічного навантаження 3 перевищенням діючих напружень умовної межі плинності при розвантаженні відбувається реверсивний поворот на $90^{\circ}$ напрямку максимальних значень коерцитивної сили, який викликає відповідний «стрибок» цุих значень. Виявлення різкої зміни значень коерцитивної сили, при перевищенні напружень умовної межі плинності, при моніторингу НДС елементів конструкиій дозволяє встановлювати межі пластично та пружно-деформованого металу й може стати обтрунтуванням для використання інших неруйнівних методів дослідження, наприклад, вимірювання товщини металу та пошуку дефектів. Застосування коерцитиметричного контролю дозволяє сепарувати пошкодження, які отримані в металі в умовах пружного деформування ц̌ пошкодження, отримані при пружно-пластичному та пластичному деформуванні, аж до руйнування. Залежність значень коерцитивної сили від орієнтації напрямку вимірювання відносно напрямку навантаження дозволяє визначати напрямок головних напружень. Наведені результати можуть бути корисними при діагностуванні якості сучасних технологій, наприклад, локальної термообробки конструктивних елементів типу «термошок» та при розробленні методики оцінювання залишкових напружень від зварювання. Отримані експериментальні результати дають оптимістичний прогноз можливості застосування коерциттиетричного контролю для моніторингу накопичення пошкоджень у феромагнітних металах після зміни значень коерцитивної сили.

Ключові слова: структуроскоп, коерцитивна сила, навантаження, пошкодження, напруження, деформація, руйнування.

https://doi.org/10.33108/visnyk_tntu2019.03.007

Отримано 29.05.2019 